\title{
ANALISIS FAKTOR YANG MEMPENGARUHI RETURN SAHAM PADA SEKTOR MANUFAKTUR DI BURSA EFEK INDONESIA 2015
}

\author{
Elvina \\ Dosen Tetap Sekolah Tinggi Ilmu Ekonomi (STIE) Labuhanbatu
}

\begin{abstract}
ABSTRAK
Penelitian ini bertujuan untuk melihat pengaruh Current Ratio, Return On Asset, Debt To Equity Ratio, Dan Price To Book Value Added terhadap return saham sektor manufkatur yang terdapat pada Bursa Efek Indonesia 2011-2013. Hipotesis dalam penelitian ini adalah 1) Current Ratio berpengaruh signifikan terhadap Return Sahampada perusahaan manufaktur di BEI, 2)Return on Asset berpengaruh signifikan terhadap Return Sahampada perusahaan manufaktur di BEI, 3) Debt to equity ratio berpengaruh signifikan terhadap Return Sahampada perusahaan manufaktur di BEI, 4) Price to book value added berpengaruh signifikan terhadap Return Sahampada perusahaan manufaktur di BEI. Populasi dalam penelitian adalah perusahaan manufaktur yang terdaftar di Bursa Efek Indonesia (BEI) pada periode tahun 20112013 yaitu sebanyak 50 perusahaan. Data dianalisis dengan menggunakan regresi berganda. Hasil penelitian menunjukkan bahwa : 1) Current Ratio berpengaruh positif dan signifikan terhadap return saham pada perusahaan manufaktur di Indonesia Periode 2011-2013., 2) Return on Asset berpengaruh positif dan signifikan terhadap return saham pada perusahaan manufaktur di Indonesia Periode 2011-2013, 3) Debt to Equity Ratio berpengaruh positif dan signifikan terhadap return saham pada perusahaan manufaktur di Indonesia Periode 2011-2013, 4) Price to Book Value Added tidak berpengaruh positif dan signifikan terhadap return saham pada perusahaan manufaktur di Inonesia Periode 2011-2013.
\end{abstract}

Kata Kunci : Current Ratio, Return on Asset, Debt to Equity Ratio, Price to Book.

\section{Pendahuluan}

Melakukan invenstasi di pasar modal merupakan salah satu bentu berinvestasi oleh investor. Dalam hal ini pasar modal didefinisikan sebagai suatu tempat berlangsungnya kegiatan yang berkaitan dengan penawaran umum dan perdagangan efek, perusahaan publik yang berkaitan dengan efek yang diterbitkannya, serta lembaga dan profesi yang berkaitan dengan efek (UU No. 8/1995 Tentang Pasar Modal).

Pengaruh pasar modal penting dalam menunjang perekonomian suatu negara. Bagi perusahaan, pasar modal merupakan suatu tempat yang dapat dimanfaatkan untuk memperoleh dana. Sementara itu bagi investor, pasar modal merupakan tempat untuk menginvestasikan dananya. Tujuan investor dalam menanamkan dana di pasar modal untuk memperoleh pendapatan. Pendapatan yang diinginkan oleh para pemegang saham adalah return saham. Return saham adalah pendapatan yang dinyatakan dalam persentase dari modal awal investasi. Pendapatan investasi dalam saham ini meliputi keuntungan jual beli saham, dimana jika untung disebut capital gain dan bila rugi disebut capital loss. Disamping capital gain, investor juga akan menerima deviden tunai tiap tahunnya.

Untuk melakukan analisis tentang return saham tersebut diperlukan adanya informasi yang bersifat fundamental dan teknikal. Analisis fundamental didasarkan pada informasiinformasi yang diterbitkan oleh emiten maupun administrator bursa efek. Analisis ini dimulai dari siklus perusahaan secara umum, selanjutnya kesektor industrinya, akhirnya dilakukan evaluasi terhadap harga saham yang diterbitkan. Sedangkan analisis teknikal didasarkan pada 
data (perubahan) harga saham di masa lalu sebagai upaya untuk memperkirakan harga saham di masa mendatang.

Analisis fundamental dipengaruhi oleh rasio-rasio keuangan yang merupakan salah satu indikator kinerja keuangan perusahaan. Pengukuran kinerja keuangan konvensional yang penting dan biasanya merupakan pusat perhatian investor maupun analis keuangan meliputi analisis terhadap posisi keuntungan kompetitif perusahaan, likuiditas aktiva perusahaan terutama yang berhubungan dengan kemampuan keuangan perusahaan di dalam memenuhi kewajiban jangka pendeknya., tingkat leverage terhadap shareholders' equity, dan komposisi dan pertumbuhan operasional penjualan perusahaan berdasarkan laporan keuangan historis. Selanjutnya diketahui rasio-rasio keuangan dan ukuran-ukuran lain yang dikaitkan dengan model pasar.

Menurut Ang (1997), rasio keuangan dapat dikelompokkan menjadi 5 macam rasio yaitu :rasio likuiditas yaitu rasio yang mengukur kemampuan likuiditas jangka pendek perusahaan dengan melihat aktiva lancar relatif terhadap hutang lancarnya, rasio solvabilitas yaitu rasio yang mengukur kemampuan perusahaan untuk memenuhi segala kewajiban jangka panjangnya rasio profitabilitas yaitu rasio yang mengukur kemampuan perusahaan memperoleh laba dalam hubungannya dengan penjualan, total aktiva maupun modal sendiri rasio Aktivitas, yaitu rasio yang mengukur seberapa jauh efektivitas perusahaan dalam mengerjakan sumber dananya dan rasio pasar yaitu rasio yang mengukur harga pasar saham relatif terhadap nilai bukunya.

\section{Perumusan Masalah}

Dari latar belakang masalah, perumusan dalam penelitian ini adalah sebagai berikut:

1. Apakah Current Ratio terhadap returnsahampada sektor manufaktur di BEI?

2. Apakah Return on Asset terhadap returnsahampada sektor manufaktur di BEI?

3. Apakah Debt to Equity Ratio terhadap returnsahampada sektor manufaktur di BEI?

4. Apakah Price to Book Value Added terhadap returnsahampada sektor manufaktur di BEI?

\section{Tujuan Penelitian}

Sesuai dengan masalah yang telah dirumuskan, maka tujuan dilakukannya penelitian ini adalah untuk mengungkapkan :

1. Pengaruh Current Ratio terhadap returnsaham pada sektor manufaktur di BEI?

2. Pengaruh Return on Asset terhadap returnsahampada sektor manufaktur di BEI?

3. Pengaruh Debt to Equity Ratio terhadap returnsahampada sektor manufaktur di BEI?

4. Pengaruh Price to Book Value Added terhadap returnsahampada sektor manufaktur di BEI? Hipotesis Penelitian

Hipotesis dalam penelitian ini adalah :

1. Current Ratio berpengaruh signifikan terhadap Return Sahampada perusahaan manufaktur di BEI.

2. Return on Asset berpengaruh signifikan terhadap Return Sahampada perusahaan manufaktur di BEI.

3. Debt to equity ratio berpengaruh signifikan terhadap Return Sahampada perusahaan manufaktur di BEI.

4. Price to book value added berpengaruh signifikan terhadap Return Sahampada perusahaan manufaktur di BEI.

\section{Tinjauan Teoritis \\ Return Saham}


Return saham merupakan hasil yang diterima dari investasi yang berupa returnrealisiasi I realized return dan return ekspektasi / expected return. Return realisasi merupakan return yang telah terjadi yang dihitung berdasarkan data historis dan digunakan sebagai salah satu pengukur kinerja perusahaan. Return realisasi ini juga berguna sebagai dasar penentuan return ekspektasi / expected return dan resiko dimasa mendatang. Return ekspektasi merupakan return yang diharapkan akan diperoleh oleh investor di masa mendatang (Pancawati et al, 2002)

\section{Current Ratio}

Current Ratio (CR) merupakan rasio likuiditas yang menunjukkan perbandingan antara Current Assets dengan Current Liabilities (Van Horne, 1997). Current Ratio mengukur kemampuan perusahaan dalam memenuhi aktiva lancar perusahaan dengan hutang lancarn Current Ratio yang tinggi menunjukkan likuiditas suatu perusahaan tersebut tinggi, dan hal ini menguntungkan bagi investor karena perusahan tersebut akan mampu menghadapi fluktuasi bisnis (Gudono, 1999).

\section{Return on Asset}

Return on Assets (ROA) merupakan salah satu rasio profitabilitas yang mengukur efektifitas perusahaan dalam menghasilkan keuntungan dengan memanfaatkan seluruh aktiva yang dimilikinya. Return on Assets sering disebut juga sebagai Returnon Investment (ROI). Return on Assets merupakan salah satu indikator keuangan yang sering digunakan dalam menilai kinerja perusahaan. Semakin besar Return on Assets maka kinerja suatu perusahaan akan semakin baik pula, karena tingkat pengembalian (return) akan semakin besar pula. Konsekuensinya, ROI yang meningkat akan meningkatkan return saham. (Hardiningsih et al, 2001)

\section{Debt to Equity Ratio}

Debt to Equity Ratio (DER) merupakan rasio solvabilitas yang digunakan untuk mengukur kemampuan modal sendiri perusahaan untuk dijadikan jaminan semua hutang perusahaan.Modigliani dan Miller (1958) dalam artikelnya yang berjudul "The Cost of Capital, Corporation Finance and the Theory of Investment" dikemukakan bahwa nilai suatu perusahaan akan meningkat dengan meningkatnya DER karena, adanya efek dari corporate tax shield. Hal ini disebabkan karena dalam keadaan pasar sempurna dan ada pajak, pada umumnya bunga yang dibayarkan akibat penggunaan hutang dapat dipergunakan untuk mengurangi penghasilan yang dikenakan pajak atau kata lain bersifat tax deductible. Dengan demikian, apabila ada dua perusahaan yang memperoleh laba operasi yang sama tetapi perusahaan yang satu menggunakan hutang dan membayar bunga sedangkan perusahaan yang lain tidak, maka perusahaan yang membayar bunga akan membayar pajak penghasilan yang lebih kecil. Karena menghemat membayar pajak merupakan manfaat bagi pemilik perusahaan, maka nilai perusahaan yang menggunakan hutang akan lebih besar dari nilai perusahaan yang tidak menggunakan hutang.

\section{Price to book value}

Price to Book Value merupakan salah satu rasio pasar yang dapat digunakan untuk mengukur kinerja harga pasar saham terhadap nilai bukunya. Rasio ini dihitung dengan cara membandingkan harga pasar per lembar saham dengan nilai buku per lembar saham. Semakin tinggi nilai PBV maka semakin tinggi pula perusahaan itu dinilai oleh investor dibandingkan dengan dana yang ditanamkan dalam perusahaan tersebut (Ang, 1997). 


\section{Pembahasan}

Berdasarkan analisis regresi berganda dan hasil pengujian hipotesis maka diketahui bahwa variabel current ratio, return on asset, debt to equity ratio dan market value added memiliki pengaruh yang positif dan signifikan terhadap return saham pada perusahaan manufaktur yang terdaftar pada Bursa Efek Indonesia periode tahun 2011-2013. Hal ini menunjukkan bahwa apabila semakin bagus current ratio, return on asset, debt to equity ratio dan market value added maka return saham perusahaan manufaktur yang terdaftar pada Bursa Efek Indonesia periode tahun 2011-2013 akan semakin meningkat.

Hasil penelitian terdahulu yang dilakukan oleh Aditya pratama yang dipublikasikan pada jurnal Akuntansi Vol.2.No1. Juni 2014 dengan judul pengaruh current ratio, debt to equity ratio, net profit margin menunjukkan adanya pengaruh yang positif dan signifikan terhadap return saham pada perusahaan manufaktur periode tahun 2008-2011 Hasil peneltian terdahulu yang dilakukan oleh Subekti Puji Astuti, SE dengan judul Analisis Pengaruh Faktor-Faktor Fundamental, Eva, Dan Mva Terhadap Return Saham Studi Pada Perusahaan Manufaktur di Bursa Efek Jakarta Periode 2001-2003 menunjukkan adanya hubungan yang positif dan signifikan antara current ratio dengan return saham .

Return saham adalah pendapatan yang dinyatakan dalam persentase dari modal awal investasi. Pendapatan investasi dalam saham ini meliputi keuntungan jual beli saham, dimana jika untung disebut capital gain dan bila rugi disebut capital loss. Disamping capital gain, investor juga akan menerima deviden tunai tiap tahunnya (Samsul, 2006). Sedangkan Konsep return atau kembalian Ang (1997) adalah tingkat keuntungan yang dinikmati oleh pemodal atas suatu investasi yang dilakukannya. Return saham merupakan income yang diperoleh oleh pemegang saham sebagai hasil dari investasinya di perusahaan tertentu

Hasil penelitian menunjukkan bahwa variabel price to book value dan economic value added tidak berpengaruh secara signifikan terhadap return saham pada perusahaan manufaktur yang terdaftar pada Bursa Efek Indonesia periode tahun 2011-2013. Nilai signifikansi variable price to book value terhadap return saham sebesar 0,417>0,05 dan $\mathrm{t}$ hitung $-0,814<\mathrm{t}$ table 1.656 . Sedangkan nilai signifikansi variabel economic value added sebesar $0,799>0,05$ dan t hitung $0.255<\mathrm{t}$ table 1.656 .

\section{Kesimpulan}

1. Current Ratio berpengaruh positif dan signifikan terhadap return saham pada perusahaan manufaktur di Indonesia Periode 2011-2013.

2. Return on Asset berpengaruh positif dan signifikan terhadap return saham pada perusahaan manufaktur di Indonesia Periode 2011-2013,

3. Debt to Equity Ratio berpengaruh positif dan signifikan terhadap return saham pada perusahaan manufaktur di Indonesia Periode 2011-2013,

4. Price to Book Value Added tidak berpengaruh positif dan signifikan terhadap return saham pada perusahaan manufaktur di Inonesia Periode 2011-2013.

\section{Saran}

Disarankan kepada perusahaan agar meningkatkan profitabilitas perusahaan agar dapat memberikan return yang lebih besar kepada pemegang saham. 


\section{DAFTAR PUSTAKA}

Bank Indonesia, 2001, Surat Edaran Bank Indonesia Nomor 3/30/DPNP/2001 tanggal 14 Desember 2001

Bank Indonesia, 2004. Surat Edaran Bank Indonesia Nomor: 6/10/PBI/2004.

Bank Indonesia,2008, Laporan Keuangan Publikasi, www.bi.go.id

Clorida Karunia (2013). Analisis pengaruh rasio capital, asset quality dan liquidity terhadap kinerja keuangan perbankan yang terdafatar di BEI tahun 2007-2011. Jurnal mahasiswa Universitas Surabaya. Vol.2.No.1.2013.

Hendra Fitrianto, 2006. Analisis Pengaruh Kualitas Aset, Intermediasi, rentabilitas Dan Efisiensi Terhadap Rasio Kecukupan Modal Perbankan Yang Terdaftar Di Bursa Efek Jakarta. volume 3, Nomor 1, Januari, Tahun 2006, Halaman 1

Kasmir,2008. Bank dan Lembaga Keuangan Lainnya. Edisi Revisi. PT Rajagrafindo. Persada, Jakarta

2010. Bank dan Lembaga Keuangan Lainnya. Raja Graffindo Pers. Jakarta.

2002. Bank dan Lembaga Keuangan Lainnya. Edisi Revisi 2002. Jakarta: PT. RAJAGRAFINDO PERSADA

Manajemen”. Edisi Revisi. Penerbit BPFE. Yogyakarta.

Peraturan Bank Indonesia No.6/10/PBI/2004menyatakan

www. Sahamok.com

www.idx.co.id 